Received: 3 October 2014

Accepted: 30 October 2014

\begin{tabular}{|c|c|c|c|c|} 
Original Paper & Mailizar Mailizar, Lecturer \\
\cline { 2 - 4 } & Syiah Kuala University, Indonesia, PhD student University of \\
Southampton, Southampton Education School, Southampton, UK
\end{tabular}

Manahel Alafaleq, PhD student

University of Southampton, Southampton

Education School, Southampton, UK

Lianghuo Fan ${ }^{1}$, PhD

University of Southampton, Southampton

Education School, Southampton, UK

\title{
A historical overview of mathematics curriculum reform and development in modern Indonesia
}

\begin{abstract}
Indonesia has the fourth largest education system in the world in terms of student population; yet due to a variety of reasons, internationally there is little literature available about Indonesian education, particularly in its historical change and development. This paper focuses on Indonesian national school mathematics curriculum, and provides a historical overview and documentation of the reform and evolution of the mathematics curriculum in modern Indonesia. Both external and internal factors in relation to Indonesian education that have influenced the mathematics curriculum reform and development in this period of time are examined and their implications to general mathematics curriculum reform and development are discussed in the paper.
\end{abstract}

Key Words: history of mathematics education, Indonesia mathematics education, mathematic curriculum reform and development.

\section{Introduction}

Located in Southeast Asia, Indonesia has the fourth largest education system in the world in terms of student population. However, large-scale International comparative studies such as the Trends in Mathematics and Science Studies (TIMSS) and the Programme for International Student Assessment

1 L.Fan@southampton.ac.uk
(PISA) have consistently shown that the Indonesian educational system does not work well in terms of students acquiring a good quality of education at the primary and secondary levels. For example, Indonesian 15-year-old students were placed $57^{\text {th }}$ out of the 65 participating countries/territories in PISA 2009 in their average mathematics scores ${ }^{2}$. In PISA 2012, they were ranked $64^{\text {th }}$ out of the 65 participating

2 See http://www.oecd.org/pisa/pisaproducts/46619703.pdf 
countries/territories. ${ }^{3}$ These indicators have been a driving force for the Indonesian government to undertake the latest national curriculum reform (Suryadarma \& Jones, 2013).

To improve the quality of students' learning in any education system, it is essential to look at its curriculum, as curriculum is a prime part of that system and plays a vital role in determining why, what, and how students learn and are taught in schools. According to Levin (2008), curriculum is defined as an official statement of what students are expected to know and be able to do. Curriculum is particularly important in countries like Indonesia, which adopts a centralized education system.

In the history of modern Indonesia's education, the national curriculum has undergone many changes in the years 1947, 1952, 1964, 1968, 1975, 1984, 1994, 1999, 2004, 2006 and the latest is 2013. As to Indonesia's national school mathematics curriculum, Soedjadi (1992, as cited in Suryanto et al., 2010) once classified this long reform into the following eras:

\section{1. before 1975 \\ 2. Era of modern mathematics \\ 3. Back to 'tradition mathematics' \\ 4. Integrated Era}

However, literatures about Indonesian mathematics education are overall very limited particularly regarding the history of mathematics curriculum. This is so even since the 1970s, the policies of education reform in Indonesia have proceeded in the context of human resources expansion for the purposes of national development (Yeom et al., 2002), and moreover, there is a growing awareness among scholars in Indonesia of the need to improve mathematics teaching in schools (Sembiring et al.,2008).

In this paper, we look back at the history of mathematics curriculum reform and development in modern Indonesia, mainly through the national

3 See http://www.oecd.org/pisa/aboutpisa/pisa-2012-participants.htm curriculum materials, policy documents and available literature. By doing so, we intend to provide a historical overview and documentation of the reform and evolution of mathematics curriculum in Indonesia, examine external and internal factors in relation to the curriculum reform and development in the country, and discuss their implications for further curriculum reform and development. We therefore start with a brief introduction about Indonesian mathematics curriculum before 1975, which we termed pre-modern mathematics curriculum.

\section{Pre-Modern Mathematics Curriculum (before 1975)}

Since Indonesia got its independence in 1945, mathematics as a school subject has been a compulsory course throughout the whole school education, that is, from primary school (Grades 1-6), to junior high school (Grades 7-9) and senior high school (Grades 10-12). However, before 1975, the teaching of mathematics was mostly influenced by Western mathematics education theories, and in particular, Skinner's behaviourism of learning (Ruseffendi, 1988). As Zulkardi (2002) noted, the lessons were delivered through mechanistic pedagogy. Students were trained to memorize mathematical concepts without understanding them (Ruseffendi, 1979). In learning geometry, for instance, Ruseffendi revealed that it was focused on developing calculation skills, and the students learned how to calculate area and volume of a geometric object without understanding the meaning of area and volume (Ruseffendi, 1979).

It should be noted that Indonesia's national mathematic curriculum before 1975 was implemented based on the separate mathematics strands such as algebra, geometry and trigonometry (Zulkardi, 2002). Regarding the contents of the curriculum, arithmetic was taught in the primary schools, algebra and plane geometry were taught in the junior high schools (Grades 7-9), while in the senior 
high schools students learned more advanced algebra, three-dimensional geometry, and analytic geometry. The main criticism of this curriculum was that it did not pay adequate attention to the relationship between different areas and topics of mathematics (Ruseffendi, 1979).

\section{Modern Mathematics Curriculum (1975)}

In 1973, the Indonesian government translated "Entebbe Mathematics Series", which was developed in mid 1960s mainly by US and UK mathematicians and mathematics educators, and aimed mainly for the African countries (Williams, 1971). The translated series were then used as main mathematics textbooks in Indonesia. This translation project was the beginning of the implementation of modern mathematics in Indonesia mathematics education.

In 1975 the Indonesian government officially implemented a new curriculum which was deeply influenced by modern mathematics movement or "new math" (Kilpatrick, 2012; Sembiring et al., 2008). According to the Ministry of Education and Culture, or Depdikbud in Indonesian, the mathematics curriculum in this period was characterized by the following criteria (Depdikbud, 1976):

1. New topics were introduced;

2. More focus was placed on developing understanding rather than memorization and calculation skills;

3. Attention was paid to continuity among the topics in primary and high schools;

4. Heterogeneous or different students' needs were accommodated;

5. Student-centred learning was emphasized.

The new topics included in the curriculum were Set, Statistics, Probability, Relation and Function, and Non-Metric Geometry (Depdikbud, 1976). Moreover, Plane Geometry and Three-Dimensional Geometry which were taught at different levels in the previous curriculum were taught at the same level, at year 11, in this curriculum.

With regard to teaching approaches, deductive approaches were used not only in geometry but also in algebra in high school. However, inductive approaches were still used for primary school students (Suherman \& Winataputra, 1999). Moreover, according to Ruseffendi (1988), this period was strongly influenced by behavioural psychology that emphasizes the stimulus to response and training (drill). In addition, Piaget and Bruner's theories also played an important role in shaping teaching approaches advocated in curriculum and classroom practices in this period (Ruseffendi, 1988).

Like in many other countries, it was also admitted that unfortunately in Indonesia also, the modern mathematics, which had been introduced into the curriculum since the beginning of 1975, resulted in a problematic situation in schools (Sembiring et al., 2008; Cockcroft, 1982). By 1983, this modern-mathematics-based curriculum was considered no longer suitable in order to meet the community's needs and the demands of science and technology. New calls for a new mathematics curriculum ensued.

\section{Technology-Integrated Curriculum (1984)}

The Indonesian government decided to develop and implement a new curriculum starting from 1984. There were actually no significant changes in terms of the total coverage of mathematics topics in the new curriculum, as compared to the previous one (Depdikbud, 1987). However, three new features make this new mathematics curriculum particularly noteworthy.

Firstly, this curriculum signalled the first attempt and policy directive to integrate modern technologies into the mathematics teaching and learning in Indonesian classrooms. Most specifically, calculators were introduced into the teaching of mathematics. It is in this sense we call this curriculum "tech- 
nology-integrated curriculum", though this was only a starting point in this direction. According to Ruseffendi (1988), this was one of important efforts in strengthening mathematics education in Indonesia.

Secondly, there was an important change in the sequence and structure of the mathematics contents introduced in the curriculum. For examples, some topics such as algorithms, trigonometry, and transformation were moved from the senior high school level to the junior high school level (Depdikbud, 1987).

Thirdly, a "spiral" approach as a pedagogy was adopted in the new curriculum. Table 1 below shows an example of how a concept of geometry (area) was packed in the curriculum (Depdikbud, 1987).

Table 1: An Example of Spiral Approach in Teaching Areas of Geometric Shapes

\begin{tabular}{|c|c|}
\hline $\begin{array}{l}\text { Grade } \\
\text { Level }\end{array}$ & Topics \\
\hline Grade 3 & $\begin{array}{l}\text { The students were introduced the ratios } \\
\text { of area of a square and rectangle, and } \\
\text { then they learned the area of a square and } \\
\text { rectangle through counting square plot. }\end{array}$ \\
\hline Grade 5 & $\begin{array}{l}\text { The students recalled what they already } \\
\text { learned at Grade } 3 \text {. Thus, they learned } \\
\text { the area of a square and rectangle by } \\
\text { multiplying the square plots on rows and } \\
\text { columns; from this activity they learned } \\
\text { the formulas of square and rectangle. }\end{array}$ \\
\hline Grade 5 & The students learned the area of a triangle. \\
\hline Grade 6 & $\begin{array}{l}\text { The students learned the area of a } \\
\text { parallelogram, then they were introduced } \\
\text { the area of a circle. }\end{array}$ \\
\hline Grade 7 & $\begin{array}{l}\text { The student recalled the concepts of the } \\
\text { area of a square and a rectangle, and then } \\
\text { they learned the area of a cube and block. }\end{array}$ \\
\hline Grade 8 & $\begin{array}{l}\text { The students learned the area of a } \\
\text { rhombus, trapezium and kite. }\end{array}$ \\
\hline Grade 8 & $\begin{array}{l}\text { The student learned the area of a circle its } \\
\text { application. }\end{array}$ \\
\hline
\end{tabular}

The "spiral" approach was reflected in the width and depth of learning materials, so that the higher the school levels, the more width and depth of the materials and lessons were provided on same topics.

Regarding teaching approaches, the Ministry of Education and Culture (or Depdikbud) recommended that the Student Active Learning (Cara Belajar Siswa Aktif or CBSA in Bahasa Indonesia) approach be adopted for learning and teaching in all schools (Depdikbud, 1987). CBSA is a teaching approach that provides the opportunity for students to be actively engaged in the learning process and with the hope that students get the maximum learning experience, in cognitive, affective, and psychomotor aspects (Pardjono, 2000). Internationally, this curriculum was mostly influenced by developmental psychology of Piaget (Flavell, 1967).

However, as Fauzan (2002) noted, the implementation of this new curriculum had also made clear a number of problems and in particular, the following:

1. An overload of subjects at the primary school level, which had resulted in the fact that the students often did not have sufficient time to master any given subject.

2. A lack of continuous assessment of the students' progress.

3. An unsatisfactory implementation of the active learning principles.

Therefore, all these problems had stirred up strong criticism from the parents and society (Depdikbud, 1997), a reason for the government to develop another new mathematics curriculum.

\section{Back-to-Basic Curriculum (1994)}

In 1994, the curriculum reform in Indonesia was signified by the change of curriculum content and teaching approaches, especially at the primary school level. In fact, as Armanto (2002) noted, the reformed curriculum in 1994 had made significant 
changes in many aspects compared with the previous curriculum launched in 1984.

Government reports (Depdikbud, 1994) indicated that the main aims of teaching mathematics in the 1994 curriculum were:

1. Students are able to effectively and efficiently deal with the dynamic world based on logical reasoning, rational and critical thinking.

2. Students are able to use mathematics and mathematical reasoning in studying other subjects.

3. Students have critical attitude, perseverance, and appreciation of mathematics.

4. Students understand mathematics deductively.

From the aims of teaching mathematics mentioned above, we can see that since 1994 the Indonesian mathematic curriculum already paid much attention to critical aspects of mathematics education such as developing students' reasoning and skills to deal with real life problems, which was not clearly stated in the previous curricula. These goals are similar to those stated by the National Council of Teachers of Mathematics (NCTM, 2000) that mathematic curriculum should prepare students for solving problem in a variety of school, home and work settings.

In order to achieve the main goals of teaching mathematics, specific instructional objectives were provided by the government for the teachers in the curriculum. The following is an example of specific instructional objectives as mentioned on GBPP, which is an Indonesian abbreviation of Curriculum Implementation Guide, published in 1994:
Table 2: An Example of Specific Instructional Objectives

\begin{tabular}{|l|l|}
\hline $\begin{array}{l}\text { General } \\
\text { instructional } \\
\text { objective }\end{array}$ & Specific Instructional Objectives \\
\hline $\begin{array}{l}\text { Students } \\
\text { are able to } \\
\text { measure the } \\
\text { size of angles } \\
\text { and areas, and } \\
\text { to understand } \\
\text { measurement } \\
\text { units }\end{array}$ & $\begin{array}{l}\text { 1) Students are able to determine the } \\
\text { area of squares and rectangles by } \\
\text { counting the number of square } \\
\text { units and/or by counting the } \\
\text { number of square units in one row } \\
\text { then multiplying it by the number } \\
\text { of rows. }\end{array}$ \\
$\begin{array}{l}\text { 2) Students are able to recognise the } \\
\text { formulas for era of squares and } \\
\text { rectangles. }\end{array}$ \\
$\begin{array}{l}\text { 3) Students are able to recognise } \\
\text { standard measurement units for } \\
\text { area. }\end{array}$ \\
\hline
\end{tabular}

In practice, it is not always possible to precisely specify the instructional objectives for some of the main aims of mathematic teaching in a given topic, therefore the main aims could become blurred (Fauzan, 2002). For instance, in teaching geometry the specific learning objectives in the 1994 curriculum were focused on remembering definition of two and three dimensional geometric objects such as square, cubes, prisms, and memorizing the characteristics of these objects, but did not refer to more broad aims of learning geometry such development of logical reasoning ability (Suydam, 1983) or interpretation of space and the environment (Moeharty, 1993). It appears that the specific leaning objectives were not well aligned with the main aims of the teaching and learning of mathematics as mentioned earlier.

In terms of the mathematics contents, fundamental changes were observed for the new school mathematics curriculum. The emphasis was placed on students' mastery of fundamental principles of mathematics, particularly at the primary school level, in which the "traditional" mathematics with a focus on calculation skills again received more attention in this curriculum (Depdikbud, 1994), and 
some "modern" topics, for instance, the Set Theory, were no longer a focus in the curriculum (Armanto, 2002). It is in this sense we call this reformed curriculum "back-to-basic curriculum". However, the idea of going back to basic emphasized in the curriculum seems contradicting or incoherent with one of the main aims of the curriculum, that is, students were expected to be able to use mathematics and mathematical reasoning in their daily life. Moreover, at the senior high school level, the introduction to graph theory was included in the curriculum while integration was not. It would be interesting to see the reason behind these changes. Unfortunately we were not able to locate any literature regarding this issue, nor could we reach the curriculum developers to gather information and make clarification due to the scope of this study, a limitation warranting further effort in future study.

\section{Content-Reduced Curriculum (1999)}

As it had too heavy content for teachers and students to get through, the 1994 curriculum was later considered overloaded (Supriyoko, 1999). Moreover, as Supriyoko also pointed out, the 1994 curriculum was not flexible so the teachers were unable to find adequate room for developing students' creativity in teaching and learning activities. In addition, Fauzan (2002) noted that teachers complained about having too many topics, too limited time to teach them, and the students complained about having too many exercises and too much homework to complete in a school year. Therefore, the government decided to make some adjustments in the national mathematics curriculum.

The new mathematics curriculum was released by the Indonesian government in 1999. It is largely a simplification of the 1994 curriculum. One of the most important features of this new curriculum was reducing so-called irrelevant or unessential topics such as sets and introduction to graph theory (Fauzan, 2002). Unfortunately, we could not find any literature concerning why these topics in particular were regarded irrelevant by the government reformers at that time.

In addition, for this curriculum, the government only required all students to master core content. For those who were more interested in mathematics or mathematical gifted students the new curriculum offered advanced mathematical contents. This advanced content was managed and adjusted by teachers based on students' needs. Some of the advanced topics were, for example, Measures of Skewness and Kurtosis, Inverse Function and Composition, the derivative and integral of the Exponential Function (Depdikbud, 1999). The new curriculum advised that the content of mathematics taught and the levels of difficulty must be continuously reviewed and updated when necessary in order to meet students' needs.

It should be noted that content reduction in mathematics curriculum was also reported in many other countries especially in Asian countries including China, Japan, and Singapore around the same time (Bjork \& Tsuneyoshi, 2005; Wu \& Zhang, 2006). For example, in Singapore, the government announced in 1998 that there was a 10\%-30\% content deduction in most school subjects including mathematics with the purpose of providing room for teachers to implement the new initiatives in schools, such as the development of thinking skills, integrating the use of Information Technology, and the delivery of the National Education (Singapore Ministry of Education, 1998) in school education. In that sense, the reform in Indonesian mathematics curriculum was consistent with many other countries.

\section{Concluding Remarks}

Since the 1970s a number of studies (Haji, 1999; Jailani, 1990) have shown the weaknesses of mathematics teaching in Indonesia. Indonesian students find it difficult to comprehend mathematical concepts, and the teaching approaches commonly 
used in Indonesian classrooms make mathematics more difficult to learn and to understand. Moreover, the results of the national examinations showed that mathematics was continuously the lowest-scoring subject (Depdikbud, 1997).

From our discussion above, we can see that Indonesian mathematic curriculum reforms were to a large extent influenced by and consistent with the trends in other countries. For instance, when "modern mathematics" became the dominant movement around the world, the Indonesian government implemented a new curriculum framed by this new trend. Modern mathematics was rated highly and expected to provide Indonesian students with a good opportunity to learn mathematics more effectively (Sembiring et al., 2008). Unfortunately, and in practice, many teachers reported many problems with this approach as modern mathematics was too difficult for their students to learn (Somerset, 1997).

As researchers have noted, even though the curriculum reforms not only focused on mathematics contents but also on teaching approaches, the teaching and learning of mathematics in Indonesian schools remained mechanistic, with teachers tending to dictate formulas and procedures to their students (Armanto, 2002; Fauzan, 2002). Hence, it seems that the curriculum reforms over the last five or so decades failed to bring significant impact on classroom teaching and students' achievement in learning mathematics, as mentioned at the beginning of the paper. To us, this indicates the challenge and complexity of curriculum reform and development, and as a developing country with ambition to improve the teaching and learning of mathematics in schools, the case of Indonesia presents a mean- ingful lesson and example for learning and study that goes beyond its own geographical boundary.

Finally, regarding the Indonesian mathematics curriculum reforms, we think the following two issues are noteworthy as a conclusion to our paper.

First, we did not find that in the period of reforms examined in our study there was a mathematics curriculum framework at the national level that could guide the country's mathematics education community in reforming or changing the mathematics curriculum. Hence, with respect to the contents of mathematics in the curriculum, it seems that the change was to some extent not well planned and articulated during the period of the reforms. We also looked at other countries, and found that, for instance, Singapore has a well-established and articulated mathematics curriculum framework that was published in 1990, which has been used as a basic guidance in framing curriculum reforms in the country ever since.

Second, another important issue in reforming curriculum is about conducting a curriculum needs assessment. As Oliva (1991) noted, a curriculum needs assessment is a process that identifies programmatic needs that must be addressed by curriculum planners. However, concerning this issue, and as Sudiarta (2003) revealed, the Indonesian government had very weak needs assessments in reforming the curriculum. More generally, how governments can conduct a curriculum needs assessment in certain educational, economic and social context is an issue that merits further attention from mathematics curriculum reformers and developers in Indonesia and other countries especially developing ones like Indonesia with a centralized education system.

\section{References}

- Armanto, D. (2002). Teaching multiplication and division realistically in Indonesian primary schools: A prototype of local instructional theory. Unpublished doctoral dissertation, University of Twente, Enschede, The Netherlands.

- Bjork, C., \& Tsuneyoshi, R. (2005). Education reform in Japan: Competing visions for the future. Phi Delta Kappan, 86(8), 619-623.

64 
- Cockcroft, W. H. (1982). Mathematics Counts. London: HMSO.

- Depdikbud [Ministry of Education and Culture]. (1976). Kurikulum sekolah menengah 1975: GBPP bidang studi Matematika [Secondary School Curriculum 1975: Mathematics Subject]. Jakarta: Balai Pustaka.

- Depdikbud [Ministry of Education and Culture]. (1987). Kurikulum dan GBPP bidang studi Matematika SD, $S M P$, dan SMA [Curriculum and curriculum implementation guide: Mathematics for primary, junior high, and senior high school]. Jakarta: Author.

- Depdikbud [Ministry of Education and Culture]. (1994). Kurikulum Pendidikan Dasar 1994 [Basic Education Curriculum 1994]. Jakarta: CV. Aneka Ilmu.

- Depdikbud [Ministry of Education and Culture]. (1994). Curriculum implementation guide. Jakarta: MOEC.

- Depdikbud [Ministry of Education and Culture]. (1999). Kurikulum pendidikan dasar [Basic education curriculum]. Jakarta: Dirjen Didasmen, Departemen Pendidikan dan Kebudayaan.

- Depdikbud [Ministry of Education and Culture]. (1997). Statistik persekolahan 1995/1996 [School Statistics]. Jakarta: Author.

- Fauzan, A. (2002). Applying realistic mathematics education in teaching geometry in Indonesian primary schools. Unpublished doctoral dissertation, University of Twente, Enschede, The Netherlands.

- Flavell, J. (1967). The developmental psychology of Jean Piaget. New York: D. Van Nostrand.

- Haji, S. (1994). Diagnosis kesulitan siswa dalam menyelesaikan soal cerita di kelas V SD Negeri Percobaan Surabaya (tesis) [Diagnosis of student difficulties in solving word problems in class V SD Negeri Surabaya Experiment (thesis)]. Malang, Indonesia: IKIP Malang.

- Jailani, J. (1990). Suatu studi pengadaan terapan matematika pada siswa SMP Negeri di Kodya Yogyakarta (tesis) [A study of the use of applied mathematics at the Junior High School students in the District of Yogyakarta (thesis)]. Malang, Indonesia: IKIP Malang.

- Kilpatrick, J. (2012). The new math as an international phenomenon. ZDM-The International Journal on Mathematics Education, 44, 563-571.

- Levin, B. (2008). Curriculum policy and the politics of what should be learned in school (in) Handbook of Curriculum and Instruction. London: SAGE.

- Moeharty. M. (1993, June). School geometry, which has been almost neglected? Paper presented at South Asian Conference for Mathematics Education, Surabaya, Indonesia.

- National Council of Teachers of Mathematics. (2000). Principles and standards for school mathematics. Reston, VA: Author.

- Oliva, P. F. (1991). Developing curriculum, a guide to principles and process. New York: Harper.

- Pardjono, P. (2000). The implementation of student active Learning in primary Mathematics in Indonesia. Unpublished doctoral dissertation, Deakin University, Burwood, Australia.

- Ruseffendi, E. T. (1985). Pengajaran Matematika moderen untuk orang tua murid, guru dan SPG, buku 6 [Modern Mathematics for parents, teachers and SPG, book 6]. Bandung, Indonesia: Tarsito.

- Ruseffendi, E. T. (1979). Pengajaran matematika moderen untuk orang tua murid, guru, dan SPG, buku 1 [Modern mathematics teaching for parents, teachers, and SPG, book 1]. Bandung, Indonesia: Tarsito. 
- Ruseffendi, E. T. (1988). Pengantar kepada membantu guru mengembangkan kompetensinya dalam pengajaran matematika untuk meningkatkan CBSA [Introduction to help teachers develop competence in teaching mathematics to improve the student active learning]. Bandung, Indonesia: Tarsito.

- Sembiring, R. K. (2010). Pendidikan matematika realistik Indonesia (PMRI): perkembangan dan tantangan [Indonesian realistic mathematics education (PMRI): progress and challenges]. Indo-MS-JME, 1(1), 11-16.

- Singapore Ministry of Education (1998). Content reduction in the curriculum. Press release, 16 July. Reference No: EDUN N25-02-004. Retrieved from http://www.moe.gov.sg/media/press/1998/980716.htm

- Soedjadi, S. (1992). Meningkatkan Minat Siswa Terhadap Matematika. Media Pendiddikan dan Ilmu Pengetahuan [Enhancing Student Interest in Math. Media Pendiddikan and Science]. Surabya, Indonesia: UNESA.

- Sembiring, R. K., Hadi, S., \& Dolk, M. (2008). Reforming mathematics learning in Indonesian classroom through RME. ZDM-International Journal on Mathematics Education, 40, 927-938.

- Somerset, A. (1997). Strengthening quality in Indonesia's junior secondary schools: An overview of issues and initiatives. Jakarta: MOEC.

- Sudiarta, P. (2003). Mencermati kurikulum berbasis kompetensi: sebuah kajian epistemologis dan praktis [Observing the competency-based curriculum: An epistemological and practical study]. Jurnal Pendidikan dan Pengajaran IKIP Negeri Singaraja. 36, 32-51.

- Suherman, E., \& Winataputra, U. (1999). Strategi belajar mengajar matematika [Mathematics teaching and learning strategies]. Jakarta: Universitas Terbuka.

- Supriyoko, K. (1999, Sept.). Beberapa catatan pelaksanaan kurikulum 1999 [Some notes on implementation of curriculum]. Pusara, 1-6.

- Suryadarma, D., \& Jones G. (2013). Education in Indonesia. Singapore: ISEAS Publishing.

- Suryanto, et al. (2010). Sejarah PMRI [A History of PMRI]. Jakarta: Ditjen Dikti Kemendiknas.

- Suydam, M. N. (1983). Classroom ideas from research secondary school mathematics. Reston, VA: NCTM.

- Williams, G. A. (1971). Report: The entebbe mathematics project. International Review of Education, 17(2), 210-214.

- Wu, M., \& Zhang, D. (2006). An overview of the mathematics curricula in the West and East- Discussions on the findings of the Chongqing paper. In F. K. S. Leung, K.-D. Graf, \& F. J. Lopez-Real (Eds.), Mathematics education in different cultural traditions: A comparative study of East Asia and the West (pp. 181-193). New York: Springer.

- Yeom, M., Acedo, C., \& Utomo, E. (2002). The reform of secondary education in Indonesia during the 1990s: Basic education expansion and quality improvement through curriculum decentralization. Asia Pacific Education Review, 3(1), 56-68.

- Zulkardi, Z. (2002). Developing a learning environment on realistic mathematics education for Indonesian student teachers. Unpublished doctoral dissertation, University of Twente, Enschede, The Netherlands. 


\section{Маилизар Маилизар}

предавач, Универзитет Сија Куала, Индонезија, докторанд, Педагошки факултет, Универзитет у Саутемптону, Велика Британија

\section{Манахел Алафелек}

докторанд, Педагошки факултет, Универзитет у Саутемптону, Велика Британија др Лиангуо Фан

Педагошки факултет, Универзитет у Саутемптону, Велика Британија

\section{Историјски осврт на математичку курикуларну реформу и развој у модерној Индонезији}

Индонезија је четврта земља у свету из области образовног система и популације ученика, мада у свету постоји врло мало литературе о индонежанском образовању, нарочито оне која се тиче историјских промена и развоја од њене независности 1945. године. У овом раду се осврћемо на историју математичке курикуларне реформе и развоја у модерној Индонезији, пре свега кроз националне курикуларне материјале, документа у вези са националном политиком и доступном литературом, и даље - до историјског осврта и документације реформе и еволуције математичког курикулума у индонежанским школама. Заснован на нашем осврту и анализи, ова модерна историја индонежанског математичког курикулума може да се подели у пет фаза: 1) Предмодерни математички курикулум (пре 1975), који је превасходно био базиран на засебним математичким стандардима, као што је алгебра, геометрија и тригонометрија. У овом курикулуму није обраћано довољно пажње на односе између различитих математичких тема; 2) Модерни математички курикулум (1975), на који је много утицала модерна математика или „нова математика“ наглашавајући структуралистички приступ. Као и у многим другим земљама, и у Индонезији је прихваћено да модерна математика, која је заснована 1975. године, доводи до проблематичних ситуација у школама; 3) Технолошки интегрисан курикулум (1984), који заправо нема битних промена у смислу опште покривености математичких тема у поређењу са претходним курикулумом. Мада су нове карактеристике овог курикулума следеће: прво, увођење калкулатора у курикулум је сигнал првог покушаја интеграције модерне технологије у математичко поучавање и учење у индонежанским школама. У овом случају, то називамо „технолошки интегрисаним курикулумом“. Друго, постоји знатна разлика у следу и структури математичког садржаја у курикулуму. Треће, спирални приступ је педагошки приступ који је био усвојен у новом курукулуму; 4) Курикулум који се заснива на повратку на основе (1994). Курикуларна реформа у Индонезији 1994. године означена је променом у курикуларном садржају и наставним принципима, нарочито на основношколском нивоу. Од циљева учења математике, у овом курикулуму је већ обраћано много пажње на критичке аспекте математичког образовања, као што је развијање вештина резоновања и оних који се тичу стварних животних проблема, у поређењу са претходним курикулумом. У математичком садржају основне промене су начињене и нагласак је на усавршавању елементарне математике, нарочито на основношколском нивоу, на коме се више пажње посветило „традиционалној математици“, са нагласком на вештине рачунања, а неке „модерне“ теме, као што је, на пример, теорија скупова, нису више биле у фокусу курикулума. Зато га 
називамо „курикулумом који се заснива на повратку на основе“; 5) Курикулум редукованог садржаја (1999) јесте ревизија претходног курикулума и настао је, пре свега, смањивањем броја математичких тема, јер је курикулум из 1994. године сматран претрпаним и недовољно флексибилним и наставници нису могли да пронађу довољно простора за развијање ученичке креативности у активностима учења и поучавања. То је поједностављење курикулума из 1994. године, и једна од најважнијих карактеристика новог курикулума је редукција такозваних тема које нису битне и основне. Можемо да закључимо да су индонежанске математичке курикуларне реформе умногоме биле под утицајем и у складу са трендовима других земаља, и следећа два става су нарочито битна. Прво, није постојао оквир националног математичког курикулума који је водио земљу у реформисање курикулума. Друго, постојала је врло слаба процена потреба у реформисању курикулума у прошлости, и наше мишљење је да начин којим се води процена потреба у одређеном образовном, економском и друштвеном контексту питање које треба да буде врло битно за математичке курикуларне реформе и развој, како у Индонезији, тако и у другим земљама.

Клучне речи: историја математичког образовања, индонежанско математичко образовање, математичка курикуларна реформа и развој. 